Walz, G., Aruffo, A., Kolanus, W., Bevilacqua, M., and Seed, B. (1990). Recognition by ELAM1 of the sialyl-Lex determinant on myeloid and tumor cells. Science 250, 1132-1135.

Wang, L., Mitoma, J., Tsuchiya, N., Narita, S., Horikawa, Y., Habuchi, T., Imai, A., Ishimura, H., Ohyama, C., and Fukuda, M. (2005). An A/G polymorphism of core 2 branching enzyme gene is associated with prostate cancer. Biochem. Biophys. Res. Commun. 331, 958-963.

Yeh, J. C., Hiraoka, N., Petryniak, B., Nakayama, J., Ellies, L. G., Rabuka, D., Hindsgaul, O., Marth, J. D., Lowe, J. B., and Fukuda, M. (2001). Novel sulfated lymphocyte homing receptors and their control by a Core1 extension beta 1,3- $N$-acetylglucosaminyltransferase. Cell 105, 957-969.

Yeh, J. C., Ong, E., and Fukuda, M. (1999). Molecular cloning and expression of a novel beta-1, 6- $N$-acetylglucosaminyltransferase that forms core 2, core 4, and I branches. J. Biol. Chem. 274, 3215-3221.

Yousefi, S., Higgins, E., Daoling, Z., Pollex-Kruger, A., Hindsgaul, O., and Dennis, J. W. (1991). Increased UDP-GlcNAc:Gal beta 1-3GaLNAc-R (GlcNAc to GalNAc) beta-1, 6- $N$-acetylglucosaminyltransferase activity in metastatic murine tumor cell lines. Control of polylactosamine synthesis. J. Biol. Chem. 266, 1772-1782.

Zhang, J., Nakayama, J., Ohyama, C., Suzuki, M., Suzuki, A., Fukuda, M., and Fukuda, M. N. (2002). Sialyl Lewis X-dependent lung colonization of B16 melanoma cells through a selectin-like endothelial receptor distinct from E- or P-selectin. Cancer Res. 62, 4194-4198.

\title{
[23] Analysis of Leukocyte Rolling In Vivo and In Vitro
}

\author{
By Markus Sperandio, John Pickard, \\ Sunil Unnikrishnan, Scott T. Acton, and Klaus Ley
}

\begin{abstract}
Leukocyte rolling is an important step for the successful recruitment of leukocytes from blood to tissues mediated by a specialized group of glycoproteins termed selectins. Because of the dynamic process of leukocyte rolling, binding of selectins to their respective counter-receptors (selectin ligands) needs to fulfill three major requirements: (1) rapid bond formation, (2) high tensile strength, and (3) fast dissociation rates. These criteria are perfectly met by selectins, which interact with specific carbohydrate determinants on selectin ligands. This chapter describes the theoretical background, technical requirements, and analytical tools needed to quantitatively assess leukocyte rolling in vivo and in vitro. For the in vivo setting, intravital microscopy allows the observation and recording of leukocyte rolling under different physiological and pathological conditions in almost every organ. Real-time and off-line analysis tools help to assess geometric, hemodynamic, and rolling parameters. Under in vitro
\end{abstract}


conditions, flow chamber assays such as parallel plate flow chamber systems have been the mainstay to study interactions between leukocytes and adhesion molecules under flow. In this setting, adhesion molecules are immobilized on plastic, in a lipid monolayer, or presented on cultured endothelial cells on the chamber surface. Microflow chambers are available for studying leukocyte adhesion in the context of whole blood and without blood cell isolation. The microscopic observation of leukocyte rolling in different in vivo and in vitro settings has significantly contributed to our understanding of the molecular mechanisms responsible for the stepwise extravasation of leukocytes into inflamed tissues.

\section{The Multistep Model of Leukocyte Recruitment}

Leukocyte recruitment as seen by intravital microscopy starts with the capture of free-flowing leukocytes to the vessel wall, followed by leukocyte rolling along the endothelial surface layer (Butcher, 1991; Ley, 1989; Springer, 1995). Both capture and rolling are mediated by selectins. During rolling, leukocytes establish intimate contact with the endothelium, which gives endothelial-bound chemokines the opportunity to interact with specific chemokine receptors expressed on leukocytes. This in turn leads to the activation of leukocyte integrins, which results in firm adhesion of the leukocyte on the endothelium (Butcher, 1991; Ley, 2002; Springer, 1995). Additional groups of adhesion and signaling molecules then mediate leukocyte transmigration into tissue (Muller, 2003).

\section{Selectins, Selectin Ligands, and Glycosyltransferases}

Selectins are professional mediators of leukocyte rolling in inflamed microvessels of nonlymphoid tissues and in high endothelial venules (HEVs) of lymphatic tissues (Bargatze et al., 1995). Three selectins have been identified in humans, mice, and other mammals: P-, E-, and L-selectin (Vestweber and Blanks, 1999). P-selectin is stored in secretory granules called WeibelPalade bodies of endothelial cells and in $\alpha$-granules of platelets. P-selectin can be rapidly mobilized to the cell surface upon activation where it serves as rolling receptor during inflammation (Sperandio and Ley, 2005). E-selectin expression on activated endothelium is induced by several pro-inflammatory cytokines such as tumor necrosis factor- $\alpha$ (TNF- $\alpha$ ) or interleukin-1 (IL-1). Its expression is controlled by nuclear factor- $\kappa \mathrm{B}$ $(\mathrm{NF}-\kappa \mathrm{B})$ and by translational mechanisms (Kraiss et al., 2003; Read et al., 1995). L-selectin is constitutively expressed on most leukocytes and shed from their surface following leukocyte activation. L-selectin is 
the predominant rolling receptor during naive lymphocyte homing to lymphatic tissue (Ley and Kansas, 2004).

All selectins belong to the C-type lectin family of glycoproteins that recognize and bind specific carbohydrate determinants on selectin ligands in a calcium-dependent fashion. These interactions are only loosely dependent on the underlying protein backbone but require the proper posttranslational glycosylation of selectin ligands. This may be the reason why many selectin ligand proteins have been identified, but few have been validated in vivo (Vestweber and Blanks, 1999). P-selectin Glycoprotein Ligand-1 (PSGL-1) has been demonstrated to function as a selectin ligand under in vivo conditions (Briskin et al., 1993; Sako et al., 1993). PSGL-1 serves as major P- and L-selectin ligand and important E-selectin ligand during inflammation (Sperandio et al., 2003; Xia et al., 2002). Mucosal Addressin Cell Adhesion Molecule-1 (MAdCAM-1) has been proposed to mediate L-selectin-dependent rolling in HEVs of gut-associated lymphatic tissue (Berlin et al., 1993).

Several glycosyltransferases have been identified to contribute to the synthesis of functional selectin ligands (Lowe, 2002). Among them are core $2 \mathrm{~N}$-acetylglucosaminyltransferase (Ellies et al., 1998), $\alpha 1-3$ fucosyltransferases FucT-VII and -IV (Maly et al., 1996; Weninger et al., 2000), a2-3 sialyltransferase ST3Gal-IV (Ellies et al., 2002), and $\beta 1-4$ galactosyltransferase-I (Asano et al., 2003). Investigations in mice lacking these glycosyltransferases revealed a broad range of rolling defects reaching from subtle changes in leukocyte rolling velocity in ST3Gal-IV ${ }^{-1-}$ mice (Ellies et al., 2002) to the loss of almost all leukocyte rolling in FucT-VII ${ }^{-1-}$ mice (Homeister et al., 2001; Weninger et al., 2000). An additional modification consisting of the sulfation of a crucial tyrosine at the $\mathrm{N}$-terminus of PSGL-1 mediated by distinct tyrosylsulfotransferases enhances P-selectin binding to PSGL-1 (Ouyang et al., 1998; Ouyang and Moore, 1998; Pouyani and Seed, 1995). Carbohydrate sulfation catalyzed by two specific carbohydrate sulfotransferases, GlcNAc6ST-1 and GlcNAc6ST-2, has been demonstrated to confer maximum affinity for L-selectin ligands in HEVs of peripheral lymph nodes (Hiraoka et al., 1999; Kawashima et al., 2005; Uchimura et al., 2005; Van Zante et al., 2003).

\section{Biomechanical Aspects of Leukocyte Rolling}

Leukocyte rolling is a remarkable process made possible by the unique properties of selectins and selectin ligands. From the biomechanical point of view, rolling can be considered a state of dynamic equilibrium whereby rapid bond formation at the leading edge is balanced by rapid bond breakage at the trailing edge of the leukocyte-endothelial contact zone 
Blood flow

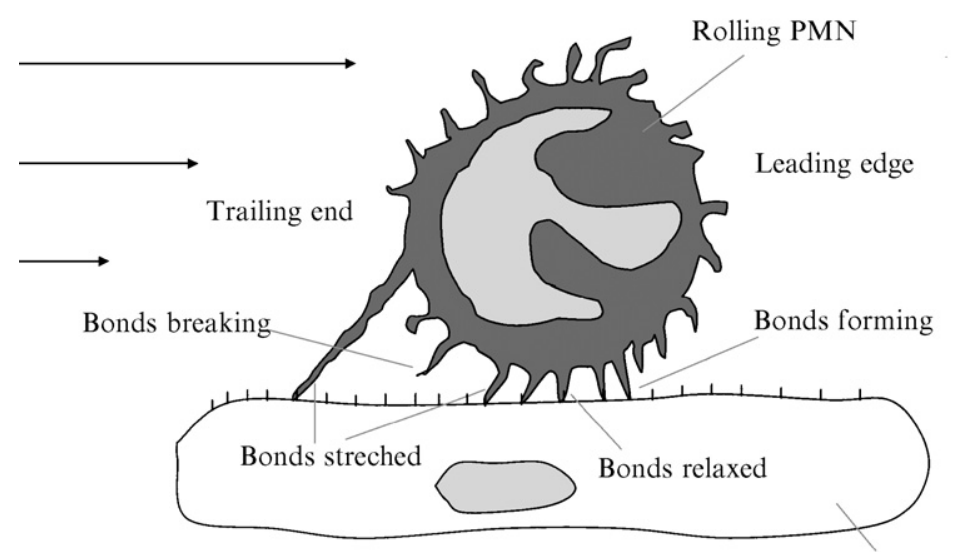

Endothelial cell

FIG. 1. Leukocyte rolling is a dynamic process whereby bonds between selectins and selectin ligands are constantly formed at the leading edge. This is followed by a short period in which bonds are in a relaxed state until they eventually become stretched and rupture at the trailing end.

(Fig. 1). As leukocytes are exposed to shear stress during rolling, force is loaded on the bonds formed between selectins and their ligands (Fig. 1). To support binding, both selectins and their ligands must be associated with the cytoskeleton (Pavalko et al., 1995). Selectin bonds are unique in that their binding strength increases with the pulling force so that the bond locks even more tightly when blood flows over the leukocyte (catch bonds) (Marshall et al., 2003; Yago et al., 2004). However, at higher pulling forces, the selectin bonds eventually break (Smith et al., 2002). These properties contribute significantly to the creation of an effective system that recruits free-flowing leukocytes to the endothelial wall and prepares them (during rolling) for subsequent adhesion and transmigration.

\section{Intravital Microscopy to Study Leukocyte Rolling In Vivo}

The direct microscopic observation of flowing blood in vivo was reported for the first time by Malpighi in 1661 who found "almost an infinite number of particles" moving in capillaries of the frog lung. Since then many modifications have enabled scientists to investigate microcirculatory phenomena 


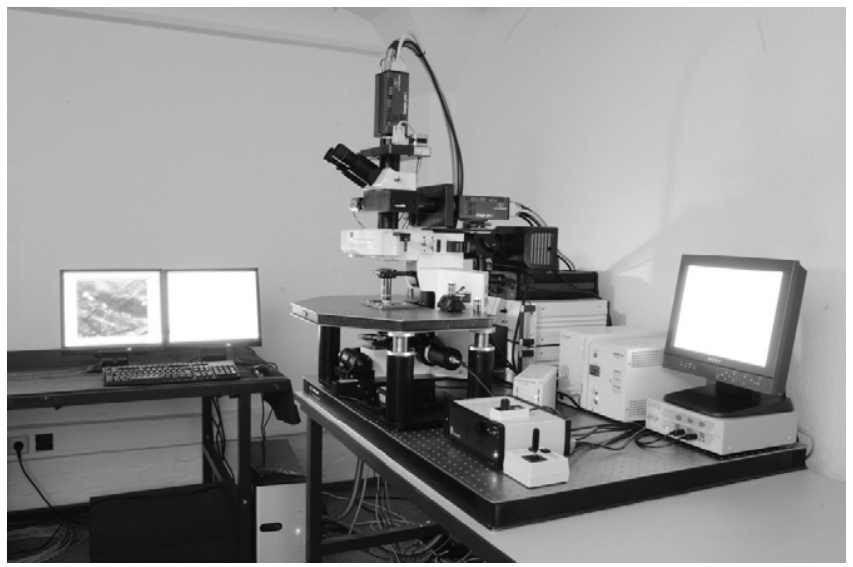

FIG. 2. Side view of a modern intravital microscope. The upright microscope is mounted onto a motorized $x y$ stage that is placed on a stable desk. Several light sources and detectors are connected to the system enabling video and/or digital recording of experiments. Filters and dichroic mirrors can be inserted at different positions in the illumination and detection pathways providing a versatile system that allows a whole variety of different microscopy techniques and experiments (Courtesy LaVision BioTec, Bielefeld, Germany.)

including leukocyte rolling and adhesion in a variety of different models and setups (Ley, 2001; Ley et al., 1987; Pries, 1988). Multiphoton laser scanning microscopy has been added to the armamentarium of intravital microscopy (Mempel et al., 2004) and may one day be used to study leukocyte rolling.

Figure 2 shows the side view of a modern intravital microscope. The different components of the setup are listed in Table I and are discussed later in this chapter. The upright microscope is fixed to a motorized $x y$-stage that is mounted on a stable optical table (Fig. 2). Hence, to examine the sample, the whole microscope with its different light sources and detectors (Table I) can be moved while the sample remains fixed in its position.

The illumination devices include conventional light sources (e.g., halogen lamp) for transillumination or reflection microscopy, as well as stroboscopic flash lamp systems (e.g., Rapp Optoelectronic, Hamburg, Germany) and continuous light $\mathrm{Hg}$ or Xe sources for epifluorescence microscopy applications (Slaaf et al., 1986). The choice of the light source depends on the particular fluorochromes and their excitation wavelengths. The mercury lamp offers some advantages for fluorochromes that are best excited at the peaks of the $\mathrm{Hg}$ spectrum. In contrast, Xe lamps have an almost continuous spectrum reaching from ultraviolet over the whole visible range, which favors its use for applications in which different fluorochromes are used. For epifluorescence applications, pulsed illumination systems offer 
TABLE I

Components of a Modern Intravital Microscope

Component

Details

Characteristics

Motorized xy-stage

Upright microscope

Optical table

Light source

Detection device

Objective lens

Condensor

Fast Filter Wheel

On-line blood flow velocity

measurement device

Video-timer

Superfusion system and

thermo-controlled

heating pad

Animal stage

Micromanipulator for

microinjections
1. Halogen lamp

2. Continuous light from

Xe- or Hg-lamp

3. Stroboscopic flash lamp system

CCD-camera with analog or digital output signal

Standard (salt) water immersion: $\times 10, \times 20, \times 40, \times 60$ with high numerical aperture

Important for transillumination microscopy applications

Digital temporal cross-correlation of intensity profiles collected by two adjacent photodiodes (Pries, 1988)

For videomicroscopy only

Different superfusion solutions are described (f.e. Klitzman and Duling, 1979)

Custom-made from Plexiglass

Micromanipulators with $\mathrm{x}-\mathrm{y}-\mathrm{z}$ axis and inclination
Moves the whole microscope while the sample is resting

Microscope type that allows the adaptation of various light sources and detectors

Stable, absorption of vibrations and shocks

Transmission/reflection experiments

Fluorescence excitation of various fluorochromes

Fluorescence excitation offering several advantages over continuous light sources

Fast CCD camera for digital recording (frame rates up to $100 \mathrm{fps}$ ) connected to high-end computer

Long working distance

Large field of view with high resolution

Köhler illumination, integration of contrast enhancing techniques (phase contrast, DIC, darkfield)

Multicolor fluorescence

Easy-to-use application, powerful bright field lamp necessary

Important component for off-line analysis Thermocontrolled environment

Support of tissue, reservoirs for superfusion 
significant advantages over continuous light sources. Most importantly, because of the long pause after each flash (the duration of one pulse is typically only a few microseconds), the phototoxic effects exerted on the living tissue under observation are significantly decreased. In addition, a proper synchronization of the flash duration and frequency to the readout cycle of the detection devices (digital camera or videocamera) enables (automated) off-line analysis of several hemodynamic parameters including blood flow velocity, leukocyte rolling velocity, and even entire velocity profiles (Long et al., 2004; Pries, 1988). Of note, placing two consecutive flashes one shortly before frame transfer and the second shortly after frame transfer produces a pair of consecutive images recorded only a few milliseconds apart (Pries, 1988). This method can be used to assess high blood flow velocities (f.e. in arterioles) that are too fast to be picked up by conventional analysis. For detection devices, many intravital microscopists use CCD cameras with analog output signal. Powerful CCD cameras are capable of recording and saving short movies directly to the computer in real time with frame transfer rates and image resolution exceeding video quality (up to $100 \mathrm{fps}$, pixel size 5-10 $\mu \mathrm{m}$ ). Although these completely digitized systems will slowly replace video recordings, it should be kept in mind that digital recording of dynamic processes such as leukocyte rolling requires the use of fast cameras that should reach frame rates of at least $20 \mathrm{fps}$. In fact, high-speed computer processors with large RAM $(>2 \mathrm{~GB})$ and hard drive capacity $(100+\mathrm{GB})$ are necessary to handle and store recorded sequences. The transfer of stored movie clips to mobile hard drives or DVD is still time consuming when compared to the routine handling of videotapes. Currently, no digital camera can produce color images at the sensitivity and speed needed for real-time fluorescence imaging.

To enable the continuous observation of microcirculatory phenomena by intravital microscopy, surgically exteriorized living tissue has to be kept warm and moist. This is achieved by superfusing the tissue with thermocontrolled $\left(37^{\circ}\right)$ bicarbonate buffered salt solution as described (Klitzman and Duling, 1979). To make the superfusion, $100 \mathrm{ml}$ of solution $\mathrm{I}(\mathrm{NaCl}$ $292.9 \mathrm{~g}, \mathrm{KCl} 13.3 \mathrm{~g}, \mathrm{CaCl}_{2} 11.2 \mathrm{~g}$, and $\mathrm{MgCl}_{2} 7.7 \mathrm{~g}$ dissolved in 3.8 liters of deionized water) is added into a 1000 -ml cylinder filled with $800 \mathrm{ml}$ deionized water. Thereafter, $100 \mathrm{ml}$ of solution II $\left(\mathrm{NaHCO}_{3} 57.5 \mathrm{~g}\right.$ dissolved in 3.8 liters of deionized water) is added. After mixing the final solution, the superfusion is equilibrated with $\mathrm{N}_{2} 95 \% / \mathrm{CO}_{2} 5 \%$ using a foam disperser. Besides its usefulness for keeping the living tissue under standardized conditions during the experiment, the superfusion fluid when used in conjunction with a (salt) water objective also offers several advantages concerning optical properties. Having water between the tissue and the 
objective helps to stabilize the optical path and increases numerical aperture. As a whole variety of different water immersion objectives are on the market, the choice of the right objective should be based not only on the magnification and the numerical aperture but also on a small objective nose providing easy access to the tissue. For most intravital microscopy applications, we use a $\times 40$ objective with a numerical aperture of 0.8 and a narrow objective nose (Carl Zeiss, Jena, Germany).

\section{Transillumination Microscopy}

Transillumination intravital microscopy has been used for more than 150 years to investigate leukocyte rolling in vivo (Wagner, 1839). Several animal models have been described. In view of the fact that the generation of knockout animals is largely restricted to mice, studies on leukocyte recruitment and rolling have mainly focused on mouse models. For the observation of leukocyte rolling during inflammation, the murine cremaster muscle preparation has become a frequently used model (Baez, 1973). The muscle is relatively thin and sufficiently vascularized. Inflammation can be induced by surgical trauma or by intrascrotal injection of proinflammatory cytokines (Jung et al., 1998; Ley et al., 1995). In contrast to the rat mesentery, which has been used for studying leukocyte rolling, the mesentery of the mouse has very few microvessels, which prevents its widespread application for studying leukocyte rolling in vivo.

Intravital microscopic experiments can be recorded by a videocamera connected to a video recorder. Leukocyte rolling and adhesion, as well as geometric and hemodynamic parameters such as vessel diameter, vessel segment length, blood flow velocity, rolling velocity, pause times, acceleration, and deceleration, are analyzed after the experiment. Centerline blood flow velocities during transillumination microscopy experiments can be measured using the dual slit photometric method originally designed by Wayland and Johnson (1967), consisting of a dual photodiode that is connected to a digital on-line temporal intensity cross-correlation program (Circusoft Instrumentation, Hockessin, USA). However, information content is limited, because only one vessel is analyzed at a time. A more advanced technology is spatial correlation with dual flash, which allows the measurement of leukocyte velocity in all vessels in the field of view (Pries, 1988).

The most recent development is microparticle image velocimetry $(\mu \mathrm{PIV})$ that yields entire flow profiles, local viscosity, shear rate, and details of near-wall effects caused by endothelial surface molecules (Long et al., 2004; Smith et al., 2003). An automated image processing software extracting all these parameters from a short recording is expected in 2007. 
Using fluorescence microscopy, centerline blood flow velocity can be determined after intravenous injection of $1 \mu \mathrm{m}$ diameter fluorescent YG microspheres (Polysciences, Warrington, PA) by measuring frame-toframe displacement of single beads located in the center of the vessel. Wall shear rates $\left(\gamma_{\mathrm{w}}\right)$ are estimated as $4.9\left(8 \mathrm{v}_{\mathrm{b}} / \mathrm{d}\right)$, where $v_{b}$ is the mean blood flow velocity and $d$ the diameter of the vessel. The constant 4.9 is a mean empirical correction factor obtained from recently described velocity profiles measured in microvessels in vivo using PIV (Long et al., 2004; Smith et al., 2003).

\section{Fluorescence Microscopy}

The observation of leukocyte rolling by fluorescence microscopy has become an essential technical tool for the dissection of lymphocyte homing in vivo. In addition, intravital fluorescence microscopy studies have also been instrumental in elucidating the role of leukocytes in ischemia/reperfusion injury of internal organs. Since its first description by von Andrian (1996), the peripheral lymph node model has become a very popular model to study leukocyte rolling in lymphatic tissue. To investigate lymphocyte trafficking into lymphatic tissue of the gut, intravital fluorescence microscopy of Peyer's patches has been used (Miura et al., 1987). Intravital microscopy of the skin and in the dorsal skin fold chamber are attractive models to study leukocyte rolling during inflammation and allergic reactions (Lehr et al., 1993; Radeke et al., 2005). Leukocyte recruitment during ischemia reperfusion injury has been studied by intravital microscopy in several organs such as the liver, intestine, and brain (Liu and Kubes, 2003). Interestingly, these studies revealed that adhesion molecules involved in leukocyte rolling may differ considerably between organs.

To visualize the cells of interest during intravital fluorescence microscopy, the cells must be labeled with a fluorescent dye. This can be achieved by isolating leukocyte subsets under in vitro conditions and injecting them during the in vivo experiment. Magnetic bead negative selection is a widespread tool to isolate a sufficient number of lymphocyte subsets. For neutrophil isolation, Percoll gradient separation has been successfully applied not only in humans but also in mice (Stark et al., 2005). For blood neutrophils, bead-based isolation techniques are used (Cotter et al., 2001). However, ex vivo isolated neutrophils do not roll normally when injected back into mice, showing that isolation procedures cause subtle activation. In vivo staining of leukocytes can easily be achieved by injection of rhodamine $6 \mathrm{G}$ or acridine orange. This method is convenient but rarely allows investigating rolling of leukocyte subsets (Janssens et al., 1989). Several green fluorescent protein (GFP)-transgenic mice have become available 
where leukocyte subsets including neutrophils and lymphocytes express GFP under control of a subset specific promoter (Faust et al., 2000; Jung et al., 2000; Manjunath et al., 1999; Singbartl et al., 2001; Unutmaz et al., 2000).

\section{Microparticle Image Velocimetry}

Complex flows often encountered in the microvasculature, like flow around adherent and rolling leukocytes, are poorly understood because of the lack of accurate quantitative data, often leading to the assumption of a parabolic profile in analysis (Sugii et al., 2002; Tangelder et al., 1986). Methods like laser Doppler velocimetry and tracking of red blood cells (RBCs) are limited by poor spatial resolution (Sugii et al., 2002; Tangelder et al., 1986). Also, near-wall velocity profiles are needed to obtain accurate wall shear stress data. Evidence of an endothelial surface layer that impedes plasma flow requires accurate near-wall velocity measurements to understand the forces involved in leukocyte adhesion to the vessel wall (Smith et al., 2003). These requirements demand high spatial resolution methods.

Particle image velocimetry (PIV) is an optical technique for velocity field measurement and visualization, widely used in traditional fields of fluid mechanics like aerodynamics and combustion. In this method, the flow is first seeded with tracer particles. It is illuminated by a plane of light at two different time points, separated by a known time interval, and the event is recorded photographically on a single image or on a succession of images. Spatial correlation techniques are then used to obtain the twodimensional velocity vectors. PIV was first extended for microfluidics in a Hele-Shaw flow around an elliptic cylinder, using 100-300 nm fluorescent particles as tracers under epi-illumination (Santiago et al., 1998). These authors were able to obtain a spatial resolution of $6.9 \times 6.9 \times$ $1.5 \mu \mathrm{m}$. Koutsiaris et al. in 1999 demonstrated the feasibility of using $\mu$ PIV in glass capillaries and the microcirculation. The development of advanced postprocessing techniques such as a combined PIV-particle tracking velocimetry (PTV) algorithm (Devasenathipathy et al., 2003; Keane et al., 1995), coupled with the advent of high-speed digital cameras, has led to a considerable improvement in spatial and temporal resolution (Shinohara et al., 2004; Sugii et al., 2005). Combined with intravital fluorescence microscopy, this technique lends itself well to in vivo animal studies because of the noninvasive nature of interrogation.

In $\mu$ PIV, unlike conventional PIV, the flow field is volume illuminated and the plane of measurement is determined by the depth of field of the microscope optics. Hence, out-of-plane particles appear progressively 
blurred as we move away from the focus and add to background noise. To define the measurement plane, it is useful to specify an intensity threshold (as a fraction of the peak in-focus intensity) below which we assume the particle does not contribute to the measurement. This measurement plane is dependent on numerical aperture, refractive index of the medium in which the objective is immersed, collected light wavelength, and particle diameter (Meinhart et al., 2000; Nguyen and Wereley, 2002). An important consideration in $\mu \mathrm{PIV}$ is the size of the particle injected in the flow. In microlevel flows, the particles themselves influence the flow, especially near the wall, so appropriate theoretical analysis should be used to correct the obtained experimental values (Smith et al., 2003). Brownian motion and surface effects also introduce errors in measurement and need to be accounted for in postprocessing algorithms (Wereley and Meinhart, 2005).

\section{Off-Line Analysis Tools: What Is Needed to Assess Leukocyte Rolling In Vivo?}

In the microcirculation, leukocytes marginate to outer blood flow layers, a phenomenon that is predominantly observed in venules. But even under conditions of maximal margination, leukocytes still move at about $50 \%$ of the centerline velocity in small venules (Gaehtgens et al., 1985). In contrast, rolling leukocytes travel with velocities that are at least one order of magnitude lower than average blood flow velocity, demonstrating the presence of adhesive interactions between leukocytes and the endothelium. Theoretical considerations based on hydrodynamic velocity near the wall (Goldman et al., 1967) led to the introduction of the term critical velocity, which defines that the slowest velocity free-flowing leukocytes can reach close to the vessel wall (see also Table II for definitions). Below critical velocity, adhesive interactions between leukocytes and endothelial cells have to be assumed (Ley and Gaehtgens, 1991). Critical velocity $\left(\mathrm{v}_{\text {crit }}\right)$ in vivo is dependent on blood flow velocity, leukocyte diameter, and vessel diameter. $v_{\text {crit }}$ can be estimated from mean blood flow velocity) $\left(\mathrm{v}_{\text {mean }}\right)$ in cylindrical vessels as $\mathrm{v}_{\text {crit }}=\mathrm{v}_{\text {mean }} \times \varepsilon \times(2-\varepsilon)$, where $\varepsilon$ is the cell to vessel diameter ratio (Ley and Gaehtgens, 1991). This gives an easily determined estimate and is accurate enough for many studies. However, better estimates became possible with $\mu$ PIV (Long et al., 2004). Leukocyte rolling velocities in inflamed cremaster muscle venules usually range from 1 to $100 \mu \mathrm{m} / \mathrm{s}$, while blood flow velocities in postcapillary venules (diameter $20-50 \mu \mathrm{m}$ ) range from 0.5 to $10 \mathrm{~mm} / \mathrm{s}$.

Using videotape recordings or digital movies, leukocyte rolling can be quantitatively assessed as leukocyte rolling flux (RF), which is the number of leukocytes crossing an imaginary line across the observed vessel (Table II). Leukocyte rolling flux is easily measured; however, it does not take into 
TABLE II

Parameters Important for the Assessment of Leukocyte Rolling by Intravital Microscopy

\begin{tabular}{|c|c|c|}
\hline Parameter & Definition & Unit \\
\hline Leukocyte rolling flux & $\begin{array}{l}\text { Number of rolling leukocytes passing a perpendicular line placed } \\
\text { across the observed vessel in one minute }\end{array}$ & $\mathrm{n} / \mathrm{min}$ \\
\hline Leukocyte rolling flux fraction & Rolling flux divided by the complete leukocyte flux & $\%$ \\
\hline Leukocyte rolling velocity & $\begin{array}{l}\text { Movement of leukocytes in intermittent and/or continuous contact } \\
\text { with the endothelial surface }\end{array}$ & $\mu \mathrm{m} / \mathrm{s}$ \\
\hline Critical velocity & $\begin{array}{l}\text { Minimal velocity of free-flowing leukocytes close to the vessel wall } \\
\text { without contact to the wall }\end{array}$ & $\mu \mathrm{m} / \mathrm{s}$ \\
\hline Vessel diameter & $\begin{array}{l}\text { Maximal orthogonal linear distance between endothelial cells on } \\
\text { opposite sides of vessel }\end{array}$ & $\mu \mathrm{m}$ \\
\hline Centerline blood flow velocity & $\begin{array}{l}\text { Converted into mean blood flow velocity by multiplying with an } \\
\text { empirical correction factor (Lipowsky and Zweifach, 1978) }\end{array}$ & $\mu \mathrm{m} / \mathrm{s}$ \\
\hline Wall shear rate & $\begin{array}{l}\gamma_{\mathrm{W}}=4.9\left(8 \mathrm{v}_{\mathrm{b}} / \mathrm{d}_{\mathrm{vessel}}\right) \\
\left(\gamma_{\mathrm{w}}: \text { wall shear rate }\right) \\
\text { (Long et al., 2004; Smith } \text { et al., 2003) }\end{array}$ & $\left(\mathrm{s}^{-1}\right)$ \\
\hline Wall shear stress & $\begin{array}{l}\tau_{\mathrm{W}}=\eta \gamma_{\mathrm{W}} \\
\left(\tau_{\mathrm{W}}: \text { wall shear stress, } \eta \text { : viscosity }\right)\end{array}$ & $\left(\mathrm{dyn} / \mathrm{cm}^{2}\right)$ \\
\hline
\end{tabular}

$\tau_{\mathrm{W}}=\eta \gamma_{\mathrm{W}}$

dyn $\left./ \mathrm{cm}^{2}\right)$ across the observed vessel in one minute 
account differences in systemic leukocyte count. This may become important in experiments in which antibody treatments are conducted. For example, injection of the L-selectin blocking monoclonal antibody ( $\mathrm{mAb}$ ) MEL-14 causes a significant drop in systemic neutrophil count (Sperandio et al., 2001). In addition, some adhesion molecule-deficient mice such as $\mathrm{CD} 18^{-1-}$ mice or P-/E-selectin ${ }^{-1-}$ mice have markedly elevated systemic leukocyte counts (Bullard, 2001). To overcome this problem, many groups assess leukocyte rolling as rolling flux fraction (RFF), which is the number of rolling cells divided by all leukocytes passing a perpendicular line in a certain time. To quantify the number of free-flowing leukocytes in postcapillary venules, fluorescent in vivo labeling of all leukocytes as described earlier can be used to count the number of free-flowing leukocytes. As a rough approximation, the number of free-flowing leukocytes can be calculated by multiplying systemic leukocyte count (cells/ $\mu \mathrm{l}$ ) and microvascular blood flow $(\mu \mathrm{l} / \mathrm{min})$. Microvascular blood flow can be obtained from measuring vascular diameter $(\mu \mathrm{m})$ and blood flow velocity $(\mu \mathrm{m} / \mathrm{s})$. Vascular diameter can easily be measured off-line using digital image processing systems (Norman, 2001; Pries, 1988). Blood flow can be deduced from centerline RBC velocity measurements using a dual photodiode and a digital cross-correlation program as described earlier. These centerline velocities can be converted to mean blood flow velocities by multiplying with an empirical factor of approximately 0.625 (Lipowsky and Zweifach, 1978).

Leukocyte rolling velocities are traditionally obtained from video or digital recordings by manually determining the position of hundreds of rolling leukocytes using a frame-by-frame analysis method, a tedious task (Jung et al., 1996). Advancements in imaging and computational techniques, in conjunction with the need to improve and accelerate the assessment of microvascular parameters, have spawned promising new automated approaches that have the additional advantage of eliminating observer bias and allow the possibility of real-time velocity assessment.

The accuracy of these algorithms is largely dependent on image quality, which can be highly variable between animals and even between vessels within the same animal. Rolling leukocytes often move in and out of the focal plane, on top of one another, and under occluding structures causing changes in intensity, cell shape, and edge sharpness. Image clutter, a result of the layered tissue, further complicates the analysis environment providing numerous interfering objects and imaging artifacts. Furthermore, animal respiration and muscle contractions result in gross tissue movement, which must be identified and corrected for. Flow chamber and microcapillary tube experiments, on the other hand, have few of these problems, and customary image processing techniques have demonstrated good results. Spatial 
filtering detection and cross-correlation, sum-of-absolute-differences, and centroid-based tracking algorithms have been used for automated particle and cell tracking analysis (Debeir et al., 2005; DiVietro et al., 2001; Ghosh and Webb, 1994; Kusumi et al., 1993). Image quality determines the best algorithm for a particular application (Cheezum et al., 2001), and, unfortunately, the lower image quality of in vivo data make these methods unsuitable for intravital experiments (Acton et al., 2002; Ray et al., 2002).

In vivo data analysis typically begins with an image enhancement step, which attempts to remove the respiratory motion artifacts, image noise, and clutter. To this end, frame differencing (optical flow) and crosscorrelation of image edges have been effectively used (Acton et al., 2002; Eden et al., 2005; Goobic et al., 2005). Vessel identification can be integrated into this step to improve processing speed and accuracy (Jinshan and Acton, 2004). The first automatically acquired in vivo rolling velocities used spatiotemporal image analysis (Sato et al., 1997); however, this analysis was confined to the imaged vessel wall and lacked exact position determinations (Eden et al., 2005). More advanced techniques exploit large intensity differences, which delineate cell borders, for template-based detection methods, which attempt to find leukocyte shaped objects (Dong et al., 2005; Gang et al., 2005; Mukherjee et al., 2004). Tracking detects cells using deformable models, specifically parametric active contours, which have shown better results than correlation or centroid trackers (Jinshan, 2002). Initially applied to in vitro cells (Leymarie and Levine, 1993), the inclusion of $a$ priori size, shape, and velocity information have allowed active contour extension to in vivo data (Ray and Acton, 2004; Ray et al., 2002). Fully integrated systems using the above methodology have been demonstrated after respiratory motion correction (Goobic et al., 2005), moving field of view registration (Dunne et al., 2004), and by real-time detection and tracking on a multiprocessor system (Jellish, 2005). Additionally, a neuralnetwork decision framework, termed CellTrack, was used on color data for cell detection and tracking (Eden et al., 2005). While none of these systems achieves $100 \%$ accuracy, a reliable computer-based tracking and data assessment system offers a rapid, highly accurate, and consistent alternative to the cumbersome and observer-biased manual work necessary to assess leukocyte rolling in vivo.

\section{Flow Chamber Assays}

Leukocyte rolling in vivo takes place in a complex environment, which is exposed to constant changes in hemodynamic and geometric parameters such as wall shear stress, volume flow rate, tube hematocrit, and vessel 
diameter. In addition, the vessel wall is covered by endothelial cells and a thick surface layer (Vink and Duling, 1996) hosting numerous adhesion molecules at variable site densities even along the same vessel segment, leading to local changes in rolling velocity or adhesion dynamics (Damiano et al., 1996; Jung and Ley, 1997). To create a more reductionist system in which interactions between different adhesion molecules can be studied on a molecular level and under clearly defined flow conditions, several flow chamber assays have been developed (Lawrence, 2001). These dynamic in vitro assays helped to identify the shear threshold for selectin-mediated rolling (Finger et al., 1996; Lawrence et al., 1997), the ability of $\alpha_{4}$-integrins to initiate lymphocyte tethering and rolling in the absence of selectins (Berlin et al., 1995), and the role of chemokines in leukocyte arrest (Campbell et al., 1998; Shamri et al., 2005).

Parallel plate flow chambers are among the most popular flow chambers used to study leukocyte rolling in vitro. They were described as early as 1912 (Burrows, 1912) but were used for the investigation of leukocyte rolling only in the late 1980s (Lawrence et al., 1987). Commercially available parallel plate flow chamber systems (www.glycotech.com) consist of two flat plates separated by a gasket, which forms a geometrically defined narrow channel between the two plates. An inflow and outflow port are used to enable the perfusion of the cell suspension through the chamber. An additional port generates a negative pressure, which keeps both plates together. To control for the flow of the cell suspension through the flow chamber, a high-precision perfusion pump is used. By knowing the geometry of the inner chamber, the flow rate of the perfusion pump $Q$, and the viscosity $\eta$, wall shear stress can be calculated as

$$
\tau_{\mathrm{w}}=(3 \eta Q) /\left(2 b a^{2}\right),
$$

where $b$ is chamber width, and $a$ is channel half height. To observe leukocyte rolling, the flow chamber is placed under an inverted microscope, which is connected to a videocamera or digital camera for recording the experiment. Two popular assays to investigate leukocyte rolling in the flow chamber are the leukocyte attachment and leukocyte detachment assay. In the attachment assay, leukocytes are perfused through the chamber at constant flow (wall shear stress: $0.5-1.5 \mathrm{dyn} / \mathrm{cm}^{2}$ ), leading to a gradual increase in the number of rolling leukocytes over time until a maximum is reached. In the detachment assay, leukocytes are infused into the chamber and flow is ceased for a little while. This gives leukocytes the chance to bind to immobilized proteins or endothelial cells. Flow is then reinitiated at very low shear stress levels (f.e. $0.05 \mathrm{dyn} / \mathrm{cm}^{2}$ ) and increased until all rolling leukocytes detach from the surface. The off-line analysis of in vitro leukocyte rolling 
assays can be accomplished by counting the number of rolling cells per field of view and per time period. Leukocyte rolling velocity can be assessed by measuring the distance leukocytes have traveled in a certain time. Several automatic tracking systems have been developed to automatically quantify the number and the velocity of rolling cells in vitro (Mangan et al., 2005; Rao et al., 2002).

\section{Autoperfused Flow Chamber}

Although flow chambers have been an important tool to study leukocyte rolling in vivo, there are several limitations such as the large dead volume of fluid within the flow system $(\sim 300 \mu \mathrm{l}$ in parallel plate flow chambers), necessitating the isolation of large quantities of cells. This prevented widespread use of flow chambers not only in the mouse system but also in experiments in which rare human leukocyte populations were investigated. The availability of genetically engineered mice that offer ideal conditions to study adhesive interactions between distinct pairs/ groups of adhesion molecules stimulated the development of new flow systems, which can be conducted with small sample volumes. Smith et al. (2004) described an ex vivo autoperfused flow chamber system in the mouse that consists of a rectangular glass capillary $(200 \times 2000 \mu \mathrm{m})$ where adhesion molecules of choice can be immobilized. After immobilization the flow chamber is placed under an upright microscope and connected via PE-tubing to the jugular vein and the carotid artery of the mouse. Because of the pressure difference between the arterial and venous side, blood is continuously driven through the flow chamber. Additional tubing connected to the venous and the arterial side is used to continuously measure the pressure drop $(\Delta \mathrm{P})$ along the glass capillary. From this measurement in conjunction with the known geometry of the chamber, wall shear stress $\left(\tau_{\mathrm{w}}\right)$ can be determined exactly and independent of any assumptions about blood viscosity as

$$
\tau_{\mathrm{w}}=\left(\Delta \mathrm{P} D_{h}\right) /(4 L),
$$

where $L$ is the length of the capillary and $D_{h}$ the hydraulic diameter. Hydraulic diameter can be calculated using

$$
D_{h}=(4 A) /(\mathrm{p}),
$$

where $A$ is the channel cross sectional area and $p$ the wetted perimeter of the cross section (Smith et al., 2004). Adhesive interactions in the flow chamber between blood constituents (i.e., leukocytes) and immobilized proteins on the glass surface can then be observed and recorded (Smith 
TABLE III

Tools to Manipulate Leukocyte Rolling

\begin{tabular}{|c|c|c|c|}
\hline Mode of manipulation & \multicolumn{2}{|c|}{ Impaired function } & References \\
\hline \multicolumn{4}{|c|}{ Genetically engineered mice targeting: } \\
\hline \multicolumn{4}{|l|}{ 1. Adhesion molecules } \\
\hline \multirow[t]{3}{*}{ Selectins: } & P-selectin & Rolling & Mayadas et al., 1993 \\
\hline & E-selectin & Slow rolling & Labow et al., 1994 \\
\hline & L-selectin & Tethering & Arbones et al., 1994 \\
\hline Selectin ligands & PSGL-1 & Rolling & $\begin{array}{l}\text { Xia et al., 2002; } \\
\text { Yang et al., } 1999\end{array}$ \\
\hline \multicolumn{4}{|c|}{ 2. Post-translational modification of selectin ligands } \\
\hline \multirow[t]{5}{*}{ Glycosyltransferases: } & FucT-VII & All selectins & Maly et al., 1996 \\
\hline & FucT-IV & E-selectin rolling & Weninger et al., 2000 \\
\hline & Core2 GlcNAcT & All selectins & Ellies et al., 1998 \\
\hline & ST3Gal-IV & E- and L-selectin & Ellies et al., 2002 \\
\hline & $\beta 1-4 \mathrm{GalT}$ & P-selectin & Asano et al., 2003 \\
\hline \multirow{2}{*}{$\begin{array}{l}\text { Carbohydrate } \\
\text { sulfotransferases }\end{array}$} & GlcNAc6ST-1 & L-selectin & Uchimura et al., 2004 \\
\hline & GlcNAc6ST-2 & L-selectin & Hemmerich et al., 2001 \\
\hline Tyrosylsulfotransferases & TST & P-selectin & $\begin{array}{l}\text { Ouyang and } \\
\text { Moore, } 1998\end{array}$ \\
\hline \multicolumn{4}{|c|}{ Blocking antibodies against selectins and selectin ligands: } \\
\hline Anti P-selectin & \multicolumn{2}{|c|}{$\begin{array}{l}\text { RB40.34 ( } \alpha \text { mouse }) \\
\text { G1 ( } \alpha \text { human })\end{array}$} & $\begin{array}{l}\text { Bosse and Vestweber, } \\
\text { 1994; Hamburger } \\
\text { and McEver, } 1990\end{array}$ \\
\hline Anti E-selectin & \multicolumn{2}{|c|}{$\begin{array}{l}\text { 9A9, RME-1 ( } \alpha \text { mouse) } \\
\text { H18/7 ( } \alpha \text { human })\end{array}$} & $\begin{array}{l}\text { Bevilacqua et al., 1987; } \\
\quad \text { Norton et al., 1993; } \\
\text { Walter } \text { et al., } 1997\end{array}$ \\
\hline Anti L-selectin & \multicolumn{2}{|c|}{$\begin{array}{l}\text { MEL-14 ( } \alpha \text { mouse }) \\
\text { DREG-56 ( } \alpha \text { human })\end{array}$} & $\begin{array}{l}\text { Gallatin et al., 1983; } \\
\quad \text { Kishimoto et al. } 1990\end{array}$ \\
\hline Anti PSGL-1 & \multicolumn{2}{|c|}{ PL-1, KPL-1 ( $\alpha$ human) } & $\begin{array}{l}\text { Frenette et al., 2000; } \\
\quad \text { Li et al., 1996; } \\
\text { Snapp et al., } 1998\end{array}$ \\
\hline
\end{tabular}

et al., 2004). This flow chamber was further miniaturized to a cross-section of $20 \times 200 \mu \mathrm{m}$ (Chesnutt et al., 2006).

Because of the small volume in the system, the rectangular glass capillaries can also be used for in vitro rolling studies by simply connecting the glass capillary to a perfusion pump. This provides superior optical conditions over round glass capillaries, which have also been used for leukocyte rolling studies (Nandi et al., 2000). If appropriate condensers, objectives, and additional accessories are chosen, microflow chamber assays with cell suspensions can also be performed on the upright microscope using contrast enhancing techniques such as phase contrast, darkfield, or differential interference contrast (DIC) microscopy. 


\section{Manipulation of Selectin-Dependent Leukocyte Rolling}

Most leukocyte rolling is mediated by selectins binding to carbohydrate structures on selectin ligands. Manipulation of these interactions can be achieved on several levels (Table III) (Sperandio et al., 2004). Adhesion molecules can be eliminated directly (gene targeted disruption of selectins or selectin ligands) or indirectly (f.e. glycosyltransferase knockout mice). At the protein level, a variety of functional blocking mAbs against selectins and selectin ligands exist and are commercially available (Table III). These antibodies can be applied during in vivo and in vitro experiments and offer the advantage that rolling can be studied before and after antibody injection and adaptive processes common in knockout mice are absent. On the other hand, incomplete blocking of leukocyte rolling either by an insufficient dose or by specificity of the used antibody has to be considered. Structural mimetics of selectin ligands have been described to block selectin ligand function under in vitro conditions (Kogan et al., 1998). This may open a new and interesting avenue to manipulate selectin-dependent rolling in vivo (Aydt and Wolff, 2002).

\section{Conclusion}

The observation of leukocyte rolling in vivo and in vitro has become an indispensable tool for the understanding of how leukocytes find their way out of the vasculature into tissue. Using intravital microscopy, combined with the advancements in genetic engineering and digital imaging, has made the mouse an ideal organism to unravel the molecular mechanisms necessary for leukocyte extravasation. The development of innovative microscopy setups such as multiphoton laser scanning intravital microscopy may further speed up the gain of knowledge on leukocyte recruitment in vivo, which will also include the observation of leukocyte subsets traveling through the different compartments of the organism.

\section{Acknowledgment}

We thank Volker Andresen, Ph.D. for helpful discussion.

\section{References}

Acton, S. T., Wethmar, K., and Ley, K. (2002). Automatic tracking of rolling leukocytes in vivo. Microvasc. Res. 63, 139-148.

Arbones, M. L., Ord, D. C., Ley, K., Ratech, H., Maynard-Curry, C., Otten, G., Capon, D. J., and Tedder, T. F. (1994). Lymphocyte homing and leukocyte rolling and migration are impaired in L-selectin-deficient mice. Immunity 1, 247-260. 
Asano, M., Nakae, S., Kotani, N., Shirafuji, N., Nambu, A., Hashimoto, N., Kawashima, H., Hirose, M., Miyasaka, M., Takasaki, S., and Iwakura, Y. (2003). Impaired selectin-ligand biosynthesis and reduced inflammatory responses in beta-1,4-galactosyltransferase-Ideficient mice. Blood 102, 1678-1685.

Aydt, E., and Wolff, G. (2002). Development of synthetic pan-selectin antagonists: A new treatment strategy for chronic inflammation in asthma. Pathobiology 70, 297-301.

Baez, S. (1973). An open cremaster muscle preparation for the study of blood vessels by in vivo microscopy. Microvasc. Res. 5, 384-394.

Bargatze, R. F., Jutila, M. A., and Butcher, E. C. (1995). Distinct roles of L-selectin and integrins $\alpha_{4} \beta_{7}$ and LFA- 1 in lymphocyte homing to Peyer's patch-HEV in situ: The multistep model confirmed and refined. Immunity 3, 99-108.

Berlin, C., Bargatze, R. F., Campbell, J. J., von Andrian, U. H., Szabo, M. C., Hasslen, S. R., Nelson, R. D., Berg, E. L., Erlandsen, S. L., and Butcher, E. C. (1995). $\alpha_{4}$ integrins mediate lymphocyte attachment and rolling under physiologic flow. Cell 80, 413-422.

Berlin, C., Berg, E. L., Briskin, M. J., Andrew, D. P., Kilshaw, P. J., Holzmann, B., Weissman, I. L., Hamann, A., and Butcher, E. C. (1993). $\alpha_{4} \beta_{7}$ integrin mediates lymphocyte binding to the mucosal vascular addressin MAdCAM-1. Cell 74, 185-195.

Bevilacqua, M. P., Pober, J. S., Mendrick, D. L., Cotran, R. S., and Gimbrone, M. A., Jr. (1987). Identification of an inducible endothelial-leukocyte adhesion molecule. Proc. Natl. Acad. Sci. USA 84, 9238-9242.

Bosse, R., and Vestweber, D. (1994). Only simultaneous blocking of the L- and P-selectin completely inhibits neutrophil migration into mouse peritoneum. Eur. J. Immunol. 24, 3019-3024.

Briskin, M. J., McEvoy, L. M., and Butcher, E. C. (1993). MAdCAM-1 has homology to immunoglobulin and mucin-like adhesion receptors and to IgA1. Nature 363, 461-464.

Bullard, D. C. (2001). Knockout mice in inflammation research. In "Physiology of Inflammation" (K. Ley, ed.), pp. 381-401. Oxford University Press, New York.

Burrows, M. T. (1912). A method of furnishing a continuous supply of new medium to a tissue culture in vitro. Anat. Rec. 6, 141-144.

Butcher, E. C. (1991). Leukocyte-endothelial cell recognition - Three (or more) steps to specificity and diversity. Cell 67, 1033-1036.

Campbell, J. J., Hedrick, J., Zlotnik, A., Siani, M. A., Thompson, D. A., and Butcher, E. C. (1998). Chemokines and the arrest of lymphocytes rolling under flow conditions. Science 279, 381-384.

Cheezum, M. K., Walker, W. F., and Guilford, W. H. (2001). Quantitative comparison of algorithms for tracking single fluorescent particles. Biophys. J. 81, 2378-2388.

Chesnutt, B. C., Smith, D. F., Raffler, N. A., Smith, M. L., White, E. J., and Ley, K. (2006). Induction of LFA-1-dependent neutrophil rolling on ICAM-1 by engagement of E-selectin. Microcirculation 13, 99-109.

Cotter, M. J., Norman, K. E., Hellewell, P. G., and Ridger, V. C. (2001). A novel method for isolation of neutrophils from murine blood using negative immunomagnetic separation. Am. J Pathol. 159, 473-481.

Damiano, E. R., Westheider, J., Tözeren, A., and Ley, K. (1996). Variation in the velocity, deformation, and adhesion energy density of leukocytes rolling within venules. Circ. Res. 79, 1122-1130.

Debeir, O., Van Ham, P., Kiss, R., and Decaestecker, C. (2005). Tracking of migrating cells under phase-contrast video microscopy with combined mean-shift processes. IEEE Trans. Med. Imaging 24, 697-711. 
Devasenathipathy, S., Santiago, B., Wereley, S. T., Meinhart, C. D., and Takehara, K. (2003). Particle imaging techniques for microfabricated fluidic systems. Exp. Fluids 34, 504-514.

DiVietro, J. A., Smith, M. J., Smith, B. R., Petruzzelli, L., Larson, R. S., and Lawrence, M. B. (2001). Immobilized IL-8 triggers progressive activation of neutrophils rolling in vitro on P-selectin and intercellular adhesion molecule-1. J. Immunol. 167, 4017-4025.

Dong, G., Ray, N., and Acton, S. T. (2005). Intravital leukocyte detection using the gradient inverse coefficient of variation. IEEE Trans. Med. Imaging 24, 910-924.

Dunne, J. L., Goobic, A. P., Acton, S. T., and Ley, K. (2004). A novel method to analyze leukocyte rolling behavior in vivo. Biol. Proced. Online. 6, 173-179.

Eden, E., Waisman, D., Rudzsky, M., Bitterman, H., Brod, V., and Rivlin, E. (2005). An automated method for analysis of flow characteristics of circulating particles from in vivo video microscopy. IEEE Trans. Med. Imaging 24, 1011-1024.

Ellies, L. G., Sperandio, M., Underhill, G. H., Yousef, J., Smith, M., Priatel, J. J., Kansas, G. S., Ley, K., and Marth, J. (2002). Sialyltransferase specificity in selectin ligand formation. Blood 100, 3618-3625.

Ellies, L. G., Tsuboi, S., Petryniak, B., Lowe, J. B., Fukuda, M., and Marth, J. D. (1998). Core 2 oligosaccharide biosynthesis distinguishes between selectin ligands essential for leukocyte homing and inflammation. Immunity 9, 881-890.

Faust, N., Varas, F., Kelly, L. M., Heck, S., and Graf, T. (2000). Insertion of enhanced green fluorescent protein into the lysozyme gene creates mice with green fluorescent granulocytes and macrophages. Blood 96, 719-726.

Finger, E. B., Puri, K. D., Alon, R., Lawrence, M. B., von Andrian, U. H., and Springer, T. A. (1996). Adhesion through L-selectin requires a threshold hydrodynamic shear. Nature 379, 266-269.

Frenette, P. S., Denis, C. V., Weiss, L., Jurk, K., Subbarao, S., Kehrel, B., Hartwig, J. H., Vestweber, D., and Wagner, D. D. (2000). P-Selectin glycoprotein ligand 1 (PSGL-1) is expressed on platelets and can mediate platelet-endothelial interactions in vivo. J. Exp. Med. 191, 1413-1422.

Gaehtgens, P., Ley, K., Pries, A. R., and Müller, R. (1985). Mutual interaction between leukocytes and microvascular blood flow. In "White Cell Rheology and Inflammation" (K. Mebmer and F. Hammersen, eds.), pp. 15-28. Basel.

Gallatin, W. M., Weissman, I. L., and Butcher, E. C. (1983). A cell-surface molecule involved in organ-specific homing of lymphocytes. Nature 304, 30-34.

Gang, D., Ray, N., and Acton, S. T. (2005). Intravital leukocyte detection using the gradient inverse coefficient of variation. IEEE Trans. Med. Imaging 24, 910-924.

Ghosh, R. N., and Webb, W. W. (1994). Automated detection and tracking of individual and clustered cell surface low density lipoprotein receptor molecules. Biophys. J. 66, $1301-1318$.

Goldman, A. J., Cox, R. G., and Brenner, B. M. (1967). Slow viscous motion of a sphere parallel to a plane wall - I Motion through a quiescent fluid. Chem. Eng. Sci. 22, 637-651.

Goobic, A. P., Tang, J., and Acton, S. T. (2005). Image stabilization and registration for tracking cells in the microvasculature. IEEE Trans. Biomed. Eng. 52, 287-299.

Hamburger, S. A., and McEver, R. P. (1990). GMP-140 mediates adhesion of stimulated platelets to neutrophils. Blood 75, 550-554.

Hemmerich, S., Bistrup, A., Singer, M. S., Van Zante, A., Lee, J. K., Tsay, D., Peters, M., Carminati, J. L., Brennan, T. J., Carver-Moore, K., Leviten, M., Fuentes, M. E., Ruddle, N. H., and Rosen, S. D. (2001). Sulfation of L-selectin ligands by an HEV-restricted sulfotransferase regulates lymphocyte homing to lymph nodes. Immunity 15, 237-247. 
Hiraoka, N., Petryniak, B., Nakayama, J., Tsuboi, S., Suzuki, M., Yeh, J. C., Izawa, D., Tanaka, T., Miyasaka, M., Lowe, J. B., and Fukuda, M. (1999). A novel, high endothelial venule-specific sulfotransferase expresses 6-sulfo sialyl lewis(x), an L-selectin ligand displayed by CD34. Immunity 11, 79-89.

Homeister, J. W., Thall, A. D., Petryniak, B., Maly, P., Rogers, C. E., Smith, P. L., Kelly, R. J., Gersten, K. M., Askari, S. W., Cheng, G., Smithson, G., Marks, R. M., Misra, A. K., Hindsgaul, O., von Andrian, U. H., and Lowe, J. B. (2001). The alpha(1,3)fucosyltransferases FucT-IV and FucT-VII exert collaborative control over selectin-dependent leukocyte recruitment and lymphocyte homing. Immunity 15, 115-126.

Janssens, C. J. J. G., Reneman, R. S., Slaaf, D. W., and Tangelder, G. J. (1989). Differentiation in vivo of leukocytes rolling in mesenteric venules of anaesthetized rabbits. J. Physiol. (London) 420, 135P.

Jellish, S. (2005). Real-time video detection and tracking of rolling leukocytes [MS Thesis]. University of Virginia, Charlottesville.

Jinshan, T., and Acton, S. T. (2004). Vessel boundary tracking for intravital microscopy via multiscale gradient vector flow snakes. IEEE Trans. Biomed. Eng. 51, 316-324.

Jinshan, T., Gang, D., Ray, N., and Acton, S. T. (2002). Evaluation of intravital tracking algorithms. The $200245^{\text {th }}$ Midwest Symposium on Circuits and Systems, 1.I-3.

Jung, S., Aliberti, J., Graemmel, P., Sunshine, M. J., Kreutzberg, G. W., Sher, A., and Littman, D. R. (2000). Analysis of fractalkine receptor CX(3)CR1 function by targeted deletion and green fluorescent protein reporter gene insertion. Mol. Cell Biol. 20, 4106-4114.

Jung, U., Bullard, D. C., Tedder, T. F., and Ley, K. (1996). Velocity difference between L-selectin and P-selectin dependent neutrophil rolling in venules of the mouse cremaster muscle in vivo. Am. J. Physiol. 271, H2740-H2747.

Jung, U., and Ley, K. (1997). Regulation of E-selectin, P-selectin and ICAM-1 expression in mouse cremaster muscle vasculature. Microcirculation 4, 311-319.

Jung, U., Ramos, C. L., Bullard, D. C., and Ley, K. (1998). Gene-targeted mice reveal importance of L-selectin-dependent rolling for neutrophil adhesion. Am. J. Physiol. 274, H1785-H1791.

Kawashima, H., Petryniak, B., Hiraoka, N., Mitoma, J., Huckaby, V., Nakayama, J., Uchimura, K., Kadomatsu, K., Muramatsu, T., Lowe, J. B., and Fukuda, M. (2005). N-acetylglucosamine-6$\mathrm{O}$-sulfotransferases 1 and 2 cooperatively control lymphocyte homing through L-selectin ligand biosynthesis in high endothelial venules. Nat. Immunol. 6, 1096-1104.

Keane, R. D., Adrian, R. J., and Zhang, Y. (1995). Super-resolution particle imaging velocimetry. Meas. Sci. Technol. 6, 754-768.

Kishimoto, T. K., Jutila, M. A., and Butcher, E. C. (1990). Identification of a human peripheral lymph node homing receptor: A rapidly down-regulated adhesion molecule. Proc. Natl. Acad. Sci. USA 87, 2244-2248.

Klitzman, B., and Duling, B. R. (1979). Microvascular hematocrit and red cell flow in resting and contracting striated muscle. Am. J. Physiol. 237, H481-H490.

Kogan, T. P., Dupre, B., Bui, H., McAbee, K. L., Kassir, J. M., Scott, I. L., Hu, X., Vanderslice, P., Beck, P. J., and Dixon, R. A. (1998). Novel synthetic inhibitors of selectinmediated cell adhesion: Synthesis of 1,6-bis[3-(3-carboxymethylphenyl)-4-(2-alpha-Dmannopyranosyloxy)phenyl]hexane (TBC1269). J. Med. Chem. 41, 1099-1111.

Koutsiaris, A. G., Mathioulakis, D. K., and Tsangaris, S. (1999). Microscope PIV for velocityfield measurement of particle suspensions flowing inside glass capillaries. Meas. Sci. Technol. 10, 1037-1046.

Kraiss, L. W., Alto, N. M., Dixon, D. A., McIntyre, T. M., Weyrich, A. S., and Zimmerman, G. A. (2003). Fluid flow regulates E-selectin protein levels in human endothelial cells by inhibiting translation. J. Vasc. Surg. 37, 161-168. 
Kusumi, A., Sako, Y., and Yamamoto, M. (1993). Confined lateral diffusion of membrane receptors as studied by single particle tracking (nanovid microscopy). Effects of calciuminduced differentiation in cultured epithelial cells. Biophys. J. 65, 2021-2040.

Labow, M. A., Norton, C. R., Rumberger, J. M., Lombard-Gillooly, K. M., Shuster, D. J., Hubbard, J., Bertko, R., Knaack, P. A., Terry, R. W., Harbison, M. L., Kontgen, F., Stewart, C. L., McIntyre, K. W., Will, P. C., Burns, D. K., and Wolitzky, B. A. (1994). Characterization of E-selectin-deficient mice: Demonstration of overlapping function of the endothelial selectins. Immunity 1, 709-720.

Lawrence, M. B. (2001). In vitro flow models of leukocyte adhesion. In "Physiology of Inflammation" (K. Ley, ed.), pp. 204-221. Oxford University Press, New York.

Lawrence, M. B., Kansas, G. S., Ghosh, S., Kunkel, E. J., and Ley, K. (1997). Threshold levels of fluid shear promote leukocyte adhesion through selectins (CD62L,P,E). J. Cell Biol. 136, 717-727.

Lawrence, M. B., McIntire, L. V., and Eskin, S. G. (1987). Effect of flow on polymorphonuclear leukocyte/endothelial cell adhesion. Blood 70, 1284-1290.

Lehr, H. A., Leunig, M., Menger, M. D., Nolte, D., and Messmer, K. (1993). Dorsal skinfold chamber technique for intravital microscopy in nude mice. Am. J. Pathol. 143, 1055-1062.

Ley, K. (1989). Granulocyte adhesion to microvascular and cultured endothelium. Studia Biophys. 34, 179-184.

Ley, K. (2001). Leukocyte recruitment as seen by intravital microscopy. In "Physiology of Inflammation" (K. Ley, ed.), pp. 303-337. Oxford University Press, New York.

Ley, K. (2002). Integration of inflammatory signals by rolling neutrophils. Immunol Rev. 186, $8-18$.

Ley, K., Bullard, D. C., Arbones, M. L., Bosse, R., Vestweber, D., Tedder, T. F., and Beaudet, A. L. (1995). Sequential contribution of L- and P-selectin to leukocyte rolling in vivo. J. Exp. Med. 181, 669-675.

Ley, K., and Gaehtgens, P. (1991). Endothelial, not hemodynamic differences are responsible for preferential leukocyte rolling in venules. Circ. Res. 69, 1034-1041.

Ley, K., and Kansas, G. S. (2004). Selectins in T-cell recruitment to non-lymphoid tissues and sites of inflammation. Nat. Rev. Immunol. 4, 325-335.

Ley, K., Pries, A. R., and Gaehtgens, P. (1987). A versatile intravital microscope design. Int. J. Microcirc. Clin. Exp. 6, 161-167.

Leymarie, F., and Levine, M. D. (1993). Tracking deformable objects in the plane using an active contour model. Anonymous. IEEE Trans Pattern, Analysis, and Machine Intelligence 15, 617-634.

Li, F., Erickson, H. P., James, J. A., Moore, K. L., Cummings, R. D., and McEver, R. P. (1996). Visualization of P-selectin glycoprotein ligand-1 as a highly extended molecule and mapping of protein epitopes for monoclonal antibodies. J. Biol. Chem. 271, 6342-6348.

Lipowsky, H. H., and Zweifach, B. W. (1978). Application of the "two-slit" photometric technique to the measurement of microvascular volumetric flow rates. Microvasc. Res. 15, 93-101.

Liu, L., and Kubes, P. (2003). Molecular mechanisms of leukocyte recruitment: Organ-specific mechanisms of action. Thromb. Haemost. 89, 213-220.

Long, D. S., Smith, M. L., Pries, A. R., Ley, K., and Damiano, E. R. (2004). Microviscometry reveals reduced blood viscosity and altered shear rate and shear stress profiles in microvessels after hemodilution. Proc. Natl. Acad. Sci. USA 101, 10060-10065.

Lowe, J. B. (2002). Glycosylation in the control of selectin counter-receptor structure and function. Immunol Rev. 186, 19-36.

Maly, P., Thall, A. D., Petryniak, B., Rogers, C. E., Smith, P. L., Marks, R. M., Kelly, R. J., Gersten, K. M., Cheng, G., Saunders, T. L., Camper, S. A., Camphausen, R. T., Sullivan, 
F. X., Isogai, Y., Hindsgaul, O., von Andrian, U. H., and Lowe, J. B. (1996). The $\alpha(1,3)$ fucosyltransferase Fuc-TVII controls leukocyte trafficking through an essential role in L-, E-, and P-selectin ligand biosynthesis. Cell 86, 643-653.

Mangan, P. R., O'quinn, D., Harrington, L., Bonder, C. S., Kubes, P., Kucik, D. F., Bullard, D. C., and Weaver, C. T. (2005). Both Th1 and th2 cells require p-selectin glycoprotein ligand-1 for optimal rolling on inflamed endothelium. Am. J. Pathol. 167, 1661-1675.

Manjunath, N., Shankar, P., Stockton, B., Dubey, P. D., Lieberman, J., and von Andrian, U. H. (1999). A transgenic mouse model to analyze CD8(+) effector T cell differentiation in vivo. Proc. Natl. Acad. Sci. USA 96, 13932-13937.

Marshall, B. T., Long, M., Piper, J. W., Yago, T., McEver, R. P., and Zhu, C. (2003). Direct observation of catch bonds involving cell-adhesion molecules. Nature 423, 190-193.

Mayadas, T. N., Johnson, R. C., Rayburn, H., Hynes, R. O., and Wagner, D. D. (1993). Leukocyte rolling and extravasation are severely compromised in $\mathrm{P}$ selectin-deficient mice. Cell 74, 541-554.

Meinhart, C. D., Wereley, S. T., and Gray, M. H. B. (2000). Volume illumination for twodimensional particle image velocimetry. Meas. Sci. Technol. 11, 809-814.

Mempel, T. R., Scimone, M. L., Mora, J. R., and vand on Andrian, U. H. (2004). In vivo imaging of leukocyte trafficking in blood vessels and tissues. Curr. Opin. Immunol. 16, 406-417.

Miura, S., Asakura, H., and Tsuchiya, M. (1987). Dynamic analysis of lymphocyte migration into Peyer's patches of rat small intestine. Lymphology 20, 252-256.

Mukherjee, D. P., Ray, N., and Acton, S. T. (2004). Level set analysis for leukocyte detection and tracking. IEEE Trans. Image Process 13, 562-572.

Muller, W. A. (2003). Leukocyte-endothelial-cell interactions in leukocyte transmigration and the inflammatory response. Trends Immunol. 24, 327-334.

Nandi, A., Estess, P., and Siegelman, M. H. (2000). Hyaluronan Anchoring and Regulation on the Surface of Vascular Endothelial Cells Is Mediated through the Functionally Active Form of CD44. J. Biol. Chem. 275, 14939-14948.

Nguyen, N.-T., and Wereley, S. T. (2002). "Fundamentals and Applications of Microfluidics." Artech House, Norwood, MA.

Norman, K. E. (2001). An effective and economical solution for digitizing and analyzing video recordings of the microcirculation. Microcirculation 8, 243-249.

Norton, C. R., Rumberger, J. M., Burns, D. K., and Wolitzky, B. A. (1993). Characterization of murine E-selectin expression in vitro using novel anti-mouse E-selectin monoclonal antibodies. Biochem. Biophys. Res. Commun. 195, 250-258.

Ouyang, Y. B., Lane, W. S., and Moore, K. L. (1998). Tyrosylprotein sulfotransferasepurification and molecular cloning of an enzyme that catalyzes tyrosine O-sulfation, a common posttranslational modification of eukaryotic proteins. Proc. Natl. Acad. Sci. USA 95, 2896-2901.

Ouyang, Y. B., and Moore, K. L. (1998). Molecular cloning and expression of human and mouse tyrosylprotein sulfotransferase-2 and a tyrosylprotein sulfotransferase homologue in Caenorhabditis elegans. J. Biol. Chem. 273, 24770-24774.

Pavalko, F. M., Walker, D. M., Graham, L., Goheen, M., Doerschuk, C. M., and Kansas, G. S. (1995). The cytoplasmic domain of L-selectin interacts with cytoskeletal proteins via $\alpha$-actinin: Receptor positioning in microvilli does not require interaction with a-actinin. J. Cell Biol. 129, 1155-1164.

Pouyani, T., and Seed, B. (1995). PSGL-1 recognition of P-selectin is controlled by a tyrosine sulfation consensus at the PSGL-1 amino terminus. Cell 83, 333-343.

Pries, A. R. (1988). A versatile video image analysis system for microcirculatory research. Int. J. Microcirc. Clin. Exp. 7, 327-345. 
Radeke, H. H., Ludwig, R. J., and Boehncke, W. H. (2005). Experimental approaches to lymphocyte migration in dermatology in vitro and in vivo. Exp. Dermatol. 14, 641-666.

Rao, R. M., Haskard, D. O., and Landis, R. C. (2002). Enhanced recruitment of Th2 and CLAnegative lymphocytes by the S128R polymorphism of E-selectin. J. Immunol. 169, 5860-5865.

Ray, N., and Acton, S. T. (2004). Motion gradient vector flow: An external force for tracking rolling leukocytes with shape and size constrained active contours. IEEE Trans. Med. Imaging 23, 1466-1478.

Ray, N., Acton, S. T., and Ley, K. (2002). Tracking leukocytes in vivo with shape and size constrained active contours. IEEE Trans. Med. Imaging 21, 1222-1235.

Read, M. A., Neish, A. S., Luscinskas, F. W., Palombella, V. J., Maniatis, T., and Collins, T. (1995). The proteasome pathway is required for cytokine-induced endothelial-leukocyte adhesion molecule expression. Immunity 2, 493-506.

Sako, D., Chang, X.-J., Barone, K. M., Vachino, G., White, H. M., Shaw, G., Veldman, G. M., Bean, K. M., Ahern, T. J., Furie, B., Cumming, D. A., and Larsen, G. R. (1993). Expression cloning of a functional glycoprotein ligand for P-selectin. Cell 75, 1179-1186.

Santiago, J. G., Wereley, S. T., Meinhart, C. D., Beebe, D. J., and Adrian, R. J. (1998). A particle image velocimetry system for microfluidics. Exp. Fluids 25, 316-319.

Sato, Y., Chen, J., Zoroofi, R. A., Harada, N., Tamura, S., and Shiga, T. (1997). Automatic extraction and measurement of leukocyte motion in microvessels using spatiotemporal image analysis. IEEE Trans. Biomed. Eng. 44, 225-236.

Shamri, R., Grabovsky, V., Gauguet, J. M., Feigelson, S., Manevich, E., Kolanus, W., Robinson, M. K., Staunton, D. E., von Andrian, U. H., and Alon, R. (2005). Lymphocyte arrest requires instantaneous induction of an extended LFA- 1 conformation mediated by endothelium-bound chemokines. Nat. Immunol. 6, 497-506.

Shinohara, K., Sugii, S., Aota, A., Hibara, A., Tokeshi, M., Kitamori, T., and Okamoto, K. (2004). High-speed micro-PIV measurements of transient flow in microfluidic devices. Meas. Sci. Technol. 15, 1965-1970.

Singbartl, K., Thatte, J., Smith, M. L., Wethmar, K., Day, K., and Ley, K. (2001). A CD2green fluorescence protein-transgenic mouse reveals very late antigen-4-dependent CD8+ lymphocyte rolling in inflamed venules. J. Immunol. 166, 7520-7526.

Slaaf, D. W., Jongsma, F. H. M., Tangelder, G. J., and Reneman, R. S. (1986). Characteristics of optical systems for intravital microscopy. In "Microcirculatory Technology" (C. H. Baker and W. L. Nastuk, eds.), pp. 211-228. Academic Press, New York.

Smith, M. L., Long, D. S., Damiano, E. R., and Ley, K. (2003). Near-wall micro-PIV reveals a hydrodynamically relevant endothelial surface layer in venules in vivo. Biophys. J. 85, 637-645.

Smith, M. L., Smith, M. J., Lawrence, M. B., and Ley, K. (2002). Viscosity-independent velocity of neutrophils rolling on p-selectin in vitro or in vivo. Microcirculation 9, 523-536.

Smith, M. L., Sperandio, M., Galkina, E. V., and Ley, K. (2004). Autoperfused mouse flow chamber reveals synergistic neutrophil accumulation through P-selectin and E-selectin. J. Leukoc. Biol. 76, 985-993.

Snapp, K. R., Ding, H., Atkins, K., Warnke, R., Luscinskas, F. W., and Kansas, G. S. (1998). A novel P-selectin glycoprotein ligand-1 (PSGL-1) monoclonal antibody recognizes an epitope within the tyrosine sulfate motif of human PSGL-1 and blocks recognition of both P- and L-selectin. Blood 91, 154-164.

Sperandio, M., Forlow, S. B., Thatte, J, Ellies, L. G., Marth, J. D., and Ley, K. (2001). Differential requirements for core2 glucosaminyltransferase for endothelial L-selectin ligand function in vivo. J. Immunol. 167, 2268-2274.

Sperandio, M., and Ley, K. (2005). The physiology and pathophysiology of P-selectin. Mod. Asp. Immunobiol. 15, 24-26. 
Sperandio, M., Linderkamp, O., and Leo, A. (2004). Blocking leukocyte rolling: Does it have a role in disease prevention? Vasc. Dis. Prev. 1, 185-195.

Sperandio, M., Smith, M. L., Forlow, S. B., Olson, T. S., Xia, L., McEver, R. P., and Ley, K. (2003). P-selectin Glycoprotein Ligand-1 mediates L-selectin-dependent leukocyte rolling in venules. J. Exp. Med. 197, 1355-1363.

Springer, T. A. (1995). Traffic signals on endothelium for lymphocyte recirculation and leukocyte emigration. Annu. Rev. Physiol. 57, 827-872.

Stark, M. A., Huo, Y., Burcin, T. L., Morris, M. A., Olson, T. S., and Ley, K. (2005). Phagocytosis of apoptotic neutrophils regulates granulopoiesis via IL-23 and IL-17. Immunity 22, 285-294.

Sugii, Y., Nishio, S., and Okamoto, K. (2002). In vivo PIV measurement of red blood cell velocity field in microvessels considering mesentery motion. Physiol. Meas. 23, 403-416.

Sugii, Y., Okuda, R., Okamoto, K., and Madarame, H. (2005). Velocity measurement of both red blood cells and plasma of in vitro blood flow using high-speed micro PIV technique. Meas. Sci. Technol. 16, 1126-1130.

Tangelder, G. J., Slaaf, D. W., Muijtjens, A. M. M., Arts, T., oude Egbrink, M. G. A., and Reneman, R. S. (1986). Velocity profiles of blood platelets and red blood cells flowing in arterioles of the rabbit mesentery. Circ. Res. 59, 505-514.

Uchimura, K., Gauguet, J. M., Singer, M. S., Tsay, D., Kannagi, R., Muramatsu, T., von Andrian, U. H., and Rosen, S. D. (2005). A major class of L-selectin ligands is eliminated in mice deficient in two sulfotransferases expressed in high endothelial venules. Nat. Immunol. 6, 1105-1113.

Uchimura, K., Kadomatsu, K., El Fasakhany, F. M., Singer, M. S., Izawa, M., Kannagi, R., Takeda, N., Rosen, S. D., and Muramatsu, T. (2004). N-acetylglucosamine 6-Osulfotransferase-1 regulates expression of L-selectin ligands and lymphocyte homing. J. Biol. Chem. 279, 35001-35008.

Unutmaz, D., Xiang, W., Sunshine, M. J., Campbell, J., Butcher, E., and Littman, D. R. (2000). The primate lentiviral receptor Bonzo/STRL33 is coordinately regulated with CCR5 and its expression pattern is conserved between human and mouse. J. Immunol. 165, 3284-3292.

Van Zante, A., Gauguet, J. M., Bistrup, A., Tsay, D., von Andrian, U. H., and Rosen, S. D. (2003). Lymphocyte-HEV interactions in lymph nodes of a sulfotransferase-deficient mouse. J. Exp. Med. 198, 1289-1300.

Vestweber, D., and Blanks, J. E. (1999). Mechanisms that regulate the function of the selectins and their ligands. Physiol. Rev. 79, 181-213.

Vink, H., and Duling, B. R. (1996). Identification of distinct luminal domains for macromolecules, erythrocytes, and leukocytes within mammalian capillaries. Circ. Res. 79, 581-589.

von Andrian, U. H. (1996). Intravital microscopy of the peripheral lymph node microcirculation in mice. Microcirculation 3, 287-300.

Wagner, R. (1839). "Erläuterungstafeln zur Physiologie und Entwicklungsgeschichte." Leopold Voss, Leipzig.

Walter, U. M., Ayer, L. M., Manning, A. M., Frenette, P. S., Wagner, D. D., Hynes, R. O., Wolitzky, B. A., and Issekutz, A. C. (1997). Generation and characterization of a novel adhesion function blocking monoclonal antibody recognizing both rat and mouse e-selectin. Hybridoma 16, 355-361.

Wayland, H., and Johnson, P. C. (1967). Erythrocyte velocity measurement in microvessels by two-slit photometric method. J. Appl. Physiol. 22, 333-337.

Weninger, W., Ulfman, L. H., Cheng, G., Souchkova, N., Quackenbush, E. J., Lowe, J. B., and von Andrian, U. H. (2000). Specialized contributions by $\alpha(1,3)$-fucosyltransferase-IV and FucT-VII during leukocyte rolling in dermal microvessels. Immunity 12, 665-676. 
Wereley, S. T., and Meinhart, C. D. (2004). Micron resolution particle image velocimetry. In "Microscale Diagnostic Techniques" (K. S. Breuer, ed.), pp. 60-65. Springer Publishing, Heidelberg, Germany.

Xia, L., Sperandio, M., Yago, T., McDaniel, J. M., Cummings, R. D., Pearson-White, S., Ley, K., and McEver, R. P. (2002). P-selectin glycoprotein ligand-1-deficient mice have impaired leukocyte tethering to E-selectin under flow. J. Clin. Invest. 109, 939-950.

Yago, T., Wu, J., Wey, C. D., Klopocki, A. G., Zhu, C., and McEver, R. P. (2004). Catch bonds govern adhesion through L-selectin at threshold shear. J. Cell Biol. 166, 913-923.

Yang, J., Hirata, T., Croce, K., Merrill-Skoloff, G., Tchernychev, B., Williams, E., Flaumenhaft, R., Furie, B., and Furie, B. C. (1999). Targeted gene disruption demonstrates that PSGL-1 is required for P-Selectin mediated but not E-Selectin mediated neutrophil rolling and migration. J. Exp. Med. 190, 1769-1782.

\title{
[24] Cell Type-Specific Roles of Carbohydrates in Tumor Metastasis
}

\author{
By Shihao Chen and Minoru Fukuda
}

\begin{abstract}
Protein- or lipid-bound glycans have been shown to play important roles in many biological processes; their functional diversity is due primarily to the multiple linkages, branching patterns, and terminal modifications seen in these glycans. Furthermore, one particular glycan may play different roles depending on the biological system. Sialyl Lewis X oligosaccharides, prototypic ligands for E-, L-, and P-selectins, are essential for naive lymphocyte homing to secondary lymphoid organs. They have also been implicated clinically in tumor metastasis and poor prognosis of cancer patients. In this chapter, we describe the protocol for the formation of lung tumor after intravenous injection of B16 melanoma cells. In our study, B16 melanoma cells formed more tumors when the cells were transfected with fucosyltransferase-III to express sialyl Lewis X. In the second experimental protocol, we describe metastatic tumor formation at the draining lymph node after primary tumor was formed at the footpad. In this experimental system, natural killer (NK) cell recruitment to the draining lymph node was found to be critical to suppress tumor metastasis and this tumor suppression is dependent on L-selectin-mediated trafficking of NK cells to the lymph nodes.
\end{abstract}

